\title{
A practical protocol for particle bombardment-mediated transformation of Phyllostachys bamboo suspension cells
}

\author{
Shinjiro Ogita*, Nanaka Kikuchi, Taiji Nomura, Yasuo Kato \\ Laboratory of Plant and Cell Engineering, Department of Biotechnology, Toyama Prefectural University, Toyama 939- \\ 0398, Japan \\ *E-mail: ogita@pu-toyama.ac.jp Tel: +81-766-56-7500 Fax: +81-766-56-2498
}

Received September 16, 2010; accepted November 1, 2010 (Edited by K. Hiratsuka)

\begin{abstract}
We developed a particle bombardment-mediated transformation protocol in Phyllostachys bamboo by optimizing the growth efficiency of a target cell culture system. Under the optimal condition, i.e. Murashige and Skoog medium containing $680 \mathrm{mg}^{-1} \mathrm{KH}_{2} \mathrm{PO}_{4}$ and $10 \mu \mathrm{M}$ Picloram, bamboo suspension cells actively proliferated at ca. $80 \mathrm{ml}$ sedimented cell volume per $100 \mathrm{ml}$ medium in 2 weeks. Log phased cells, i.e. 8 to 13-day-old suspension cells, which showed synchronous cell divisions with uniform morphology, were selected for the bombardment. We found that a target distance, $6 \mathrm{~cm}$ was much better for the transient gene expression (222 GUS-positive cells/dish/shot in average) than that of $9 \mathrm{~cm}$ (38 GUS-positive cells/dish/shot in average) in the target cells. When the bombardment was carried out using lag phased cells, e.g. 5-d-old cells, no or less GUS-positive cells could be seen. A high generation of stable transgenic bamboo cells was achieved with constructs expressing hygromycin phosphotransferase gene and enhanced fluorescent protein genes namely AcGFPl and mCherry.
\end{abstract}

Key words: Bamboo, fluorescent protein gene, particle bombardment, Phyllostachys nigra, suspension culture.

Suspension cell culture systems are highly applicable for investigating various aspects of plant cell biology. For example, the BY-2 cell line of tobacco (Nicotiana tabacum cv. 'Bright Yellow 2') is the most eminent cell line which is used to study different aspects of plant cell biology (Lee et al. 2008; Nagata et al. 1992; Nagata and Kumagai 1999). Furthermore, suspension cell lines such as the T87 line of Arabidopsis (Arabidopsis thaliana L. Heynh., ecotype Columbia) and the Oc line of rice (Oryza saliva L. C5924) had been established (Axelos et al. 1992; Baba et al. 1986) and are currently used as model plant cell lines (e.g. these cell lines are supplied at Bioresource Center, RIKEN, Japan, http://www.brc. riken.jp/lab/epd/Eng/catalog/pcellc.shtml).

We have previously described a bamboo (Phyllostachys nigra Munro var. Henonis) callus and suspension cell culture system and its application in the field of cell biology (Ogita 2005). Since the bamboo cells showed unique growth and metabolic features, such as carbohydrate metabolism and cell wall related biosynthesis in comparison with those of BY-2 and Oc cells (Ogita et al. 2008), we have been focusing on establishing a transformation protocol for investigating further metabolic functions of the bamboo cells. At present, little information is available concerning the transformation of bamboo plants. The purpose of this study was to develop a practical and efficient transformation protocol using bamboo suspension cells. Technical details for maintaining high growth efficiency of bamboo calli/suspension cells are discussed. Based on the established suspension cell culture system, we have succeeded in generating stable transgenic bamboo suspension cells using the particle bombardment method with enhanced green and red fluorescent protein (FP) genes as marker genes (Anderson et al. 2006).

\section{Materials and methods}

\section{Cell cultures}

Callus culture of $P$. nigra, which had been established previously (Ogita 2005), was maintained on modified half strength Murashige and Skoog (Murashige and Skoog 1962) medium (m1/2MS) supplemented with $3 \mu \mathrm{M}$ 2,4dichlorophenoxyacetic acid (2,4-D). Subculture was carried out on the m1/2MS medium at ca. 4-week intervals. The cultures were incubated in the dark at $25^{\circ} \mathrm{C}$.

Cell suspension culture was also generated as described by Ogita et al. (2008). Approximately $1 \mathrm{~g}$ fresh weight of callus tissues was suspended in $100 \mathrm{ml}$ liquid $\mathrm{m} 1 / 2 \mathrm{MS}$ medium of the same compositions as the maintenance medium in a $300-\mathrm{ml}$ flask. The flasks were placed on a rotary shaker with a speed of $100 \mathrm{rpm}$ in the dark at $25^{\circ} \mathrm{C}$. Suspension cells were generated within 3 weeks after the initial culture. A portion of the

This article can be found at http://www.jspcmb.jp/ 
liquid suspension cells (ca. 2-4 ml) was transferred to the maintenance medium at ca. 2-week intervals in order to maintain their stable morphology and synchronous growth.

\section{Optimization of growth efficiency of calli}

In order to optimize the condition for proliferation of bamboo callus, m1/2MS media (solidified with $0.3 \%(\mathrm{w} / \mathrm{v})$ gellan gum) supplemented with 3,5 , and $10 \mu \mathrm{M}$ of 2,4-D, 2,4,5-trichlorophenoxyacetic acid (2,4,5-T), or 4-amino-3,5,6trichloropyridine-2-carboxylic acid (Picloram) were prepared. Callus tissues (ca. $50 \mathrm{mg}$ fresh weight) were cultured on a Petri dish. After 14 and 28 days, fresh weight of 6 calli in each condition was measured. Similarly, effects of different concentrations of potassium dihydrogen phosphate $\left(\mathrm{KH}_{2} \mathrm{PO}_{4}\right)$, i.e. $85,170,340$, and $680 \mathrm{mgl}^{-1}$, in $\mathrm{ml} / 2 \mathrm{MS}$ and $\mathrm{MS}$ basal media on callus growth were also investigated. All cultures were incubated in the dark at $25^{\circ} \mathrm{C}$.

\section{Optimization of growth efficiency of suspension cells}

Based on the growth features of calli, sedimented cell volume (SCV) in $\mathrm{m} 1 / 2 \mathrm{MS}$ supplemented with $3 \mu \mathrm{M}$ 2,4-D (original medium) and MSp680 supplemented with $680 \mathrm{mgl}^{-1} \mathrm{KH}_{2} \mathrm{PO}_{4}$ and $10 \mu \mathrm{M}$ Picloram (revised medium), was measured during the $14 \mathrm{~d}$ of subculture period. Briefly, $2.5 \mathrm{ml}$ cells in SCV were initially transferred to $100 \mathrm{ml}$ liquid original or revised medium, i.e. $2.5 \%(\mathrm{v} / \mathrm{v})$ initial cell density, in a $300-\mathrm{ml}$ flask. The flasks were placed on a rotary shaker with a speed of $100 \mathrm{rpm}$ for 2 weeks in the dark at $25^{\circ} \mathrm{C}$. The SCV was measured by holding a liquid suspension cells for $15 \mathrm{~min}$ in a $50 \mathrm{ml}$ centrifugation tube graduated in milliliters. Furthermore, the cultured suspension cells were collected, fixed using $4 \%$ $(\mathrm{v} / \mathrm{v})$ glutaraldehyde solution in sodium phosphate buffer (0.1 M, pH 7.2), and dehydrated with the ethyl alcohol series. After dehydration, they were stained with $0.5 \mu \mathrm{M}$ Sytox Green and observed using a laser scanning microscope (LSM510 META, Zeiss, Germany) for characterization of the frequency of division and/or enlargement patterns of the cells.

\section{Vectors for transformation}

The pBIH1-IG vector (Ohta et al. 1990), carrying the hygromycin phosphotransferase gene (HPT) and the neomycin phosphotransferase II gene (NPT II) as the selection markers, was used as the backbone for the expression vector. The original intron-GUS sequence of the pBIH1-IG at the XbaI and $\mathrm{SacI}$ sites located between the cauliflower mosaic virus (CaMV) 35S promoter and the nopaline synthase (NOS) terminator was replaced with a green florescent protein gene (AcGFPl) or a red florescent protein gene (mCherry) originated from the pAcGFP1 vector or the pmCherry vector (Clontech Laboratories, Inc., USA) as shown in Figure 1. The pBIH1-IG vector was used for transient transformation of bamboo cells, and pBIH1-GFP and pBIH1-RFP vectors were used for stable transformation of bamboo cells.

\section{Transformation}

Gold particles, $0.6 \mu \mathrm{m}$ in diameter, were coated with the plasmid DNA according to the manufacture's protocol with modification. The DNA-coated microprojectiles, $498 \mu \mathrm{g}$ gold particles with $0.83 \mu \mathrm{g}$ DNA, per 1 shot were prepared. A portion of a callus (ca. $2 \mathrm{~g}$ fresh weight) or suspended cells (ca. $0.5 \mathrm{ml}$ in SCV) was placed in a center of Petri dish which contained the revised medium with $10 \mu \mathrm{M}$ Picloram. The dish was set at 6 or $9 \mathrm{~cm}$ below the stopping screen as the target distance. The bombardment was carried out once using the Biolistic Particle Delivery System (PDS-1000/He, Bio-Rad, USA) at 1100 psi of helium pressure.

Seven to fourteen days after bombardment, the cells were transferred to a selection medium supplemented with 50$100 \mathrm{mg}^{-1}$ hygromycin. They were then subcultured at 2- to 4 week intervals onto fresh selection medium.

\section{Detection of transformants}

Transient expression of GUS gene in bombarded bamboo cells was assayed histochemically according to Kosugi et al. (1990) with modification. The GUS assay solution which contained $1.9 \mathrm{mM}$ 5-bromo-4-chloro-3-indolyl glucuronide (X-Gluc), $20 \%$ methanol, $0.5 \mathrm{mM}$ potassium ferricyanide, $0.5 \mathrm{mM}$ potassium ferrocyanide, $0.3 \%$ Triton $\mathrm{X}-100$ in $0.1 \mathrm{M}$ sodium phosphate buffer ( $\mathrm{pH}$ 7.0) was added to the bombarded cells in a Petri dish. The dish was incubated overnight at $37^{\circ} \mathrm{C}$, and then the blue-colored GUS-expressing cells were counted under a stereo microscope.

Stable transformed cells were finally selected in MSp680 medium containing $100 \mathrm{mgl}^{-1}$ hygromycin. Expression patterns of AcGFPl and mCherry were observed under a fluorescence stereo microscope (SteREO Lumar.V12, Zeiss, Germany) and the LSM. The emission data and images of cells were acquired using lambda scan mode and plane mode, respectively according to Anderson et al. (2006) and Lee et al. (2008) with modification.

Genomic DNA was extracted from hygromycin resistant cells with an ISOPLANT II kit (Nippon gene, Japan) and subjected to PCR analysis using three sets of gene specific primers; for $H P T, 5^{\prime}$-GCGTGACCTATTGCATCTCC-3' and 5'-TTCTACACAGCCATCGGTCC-3'; for AcGFP1, 5'-GCTACATCCAGGAGCGCACC-3' and 5'-GGGGAGCTCTCACTTGTACAGCTCATCCATGC-3'; for $m$ Cherry, 5'-CCCGACTACTTGAAGCTGTCC-3' and 5'-GGGGAGCTCCTACTTGTACAGCTCGTCCATGC-3'. Similarly, RT-PCR was performed to verify the stable transcription of transgenes. Total RNA was prepared from antibiotic-resistant and genomic PCRpositive cells with an RNeasy Plant Mini kit (Qiagen, Germany) and subjected to RT-PCR using SuperScript III FirstStrand Synthesis System for RT-PCR (Invitrogen, USA) with the gene specific primers described above. PCR was performed in a $20 \mu \mathrm{l}$ reaction mixture containing $2 \mu \mathrm{l}$ of $2 \mathrm{mM}$ dNTP, $2 \mu \mathrm{l}$ of $10 \times$ Blend Taq buffer, 0.5 unit of Blend Taq polymerase (Toyobo, Japan), $1 \mu \mathrm{l}$ of primers $(10 \mu \mathrm{M})$ and $100 \mathrm{ng}$ of template genomicDNA/cDNA/RNA (10 ng of template in case of vector control). The amplification reaction was carried out under the conditions of up to 40 -cycle of denaturation at $96^{\circ} \mathrm{C}$ for $30 \mathrm{~s}$, annealing at $60^{\circ} \mathrm{C}$ for $30 \mathrm{~s}$ and extension at $72^{\circ} \mathrm{C}$ for $1 \mathrm{~min}$. The amplified DNAs were detected with ethidium bromide staining after agarose gel electrophoresis. 


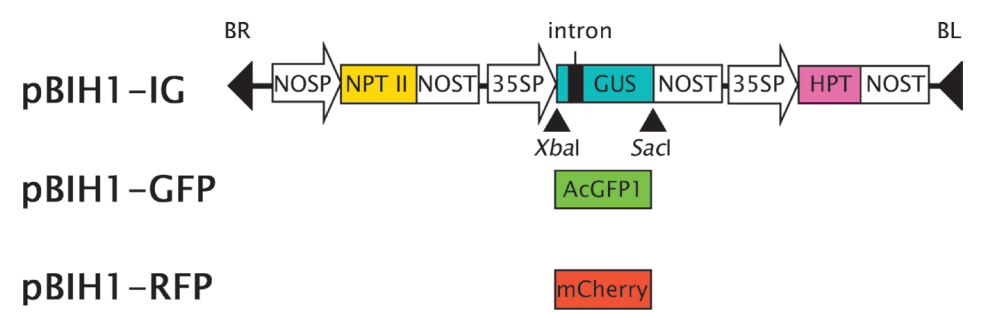

Figure 1. Transformation vectors. The GUS gene in the pBIH1-IG vector was replaced with AcGFPI or $m$ Cherry gene at the XbaI and SacI sites.

\section{Results}

\section{Effects of auxins and $\mathrm{KH}_{2} \mathrm{PO}_{4}$ on callus growth}

Since growth efficiency of target cells/tissues is one of the most important factors for transformation work (e.g. Cheng et al. 2004), we first optimized medium conditions for proliferation of bamboo calli. The growth efficiency varied depending on the kind of auxin used and its concentration tested. Bamboo calli actively proliferated during 2-4 weeks of culture. Compared with $\mathrm{m} 1 / 2 \mathrm{MS}$ medium containing $3 \mu \mathrm{M}$ 2,4-D (Figure 2A), Picloram was effective in enhancing callus growth (Figure 2C). Approximately $1.0 \mathrm{~g}$ of calli (20.0-fold) was obtained on $10 \mu \mathrm{M}$ Picloram containing medium while $0.7 \mathrm{~g}$ of calli (14.6-fold) proliferated on the original condition. In contrast, 2,4,5-T containing media showed a suppressive effect for callus growth in all concentrations tested (Figure 2B). Next, we investigated the effect of $\mathrm{KH}_{2} \mathrm{PO}_{4}$ for further enhancement of proliferation of bamboo calli. As a regulatory factor, $680 \mathrm{mg} \mathrm{l}^{-1} \mathrm{KH}_{2} \mathrm{PO}_{4}$ was quite effective in enhancing callus growth (Figure 2D). Approximately $1.7 \mathrm{~g}$ of calli (34.0-fold) proliferated on $10 \mu \mathrm{M}$ Picloram containing modified MS medium (MSp680) while $0.6 \mathrm{~g}$ of calli (11.0-fold) proliferated on the original medium. Based on these findings, we investigated the process and frequency of cell division in liquid media in order to identify an appropriate period for further transformation work.

\section{Growth efficiency of suspension cells}

Changes in the SCV value during the subculture period were monitored as shown in Figure 3A. Bamboo suspension cells in both original and revised media showed a typical growth pattern. There was a lag growth phase for $7 \mathrm{~d}$, after that, the suspension cells under the revised medium condition showed a more active proliferation pattern than the original medium during day $8-14$ of the culture period. Approximately $80 \%(\mathrm{v} / \mathrm{v})$ SCV of cells (32.0-fold) proliferated in the revised medium condition while $38 \%(\mathrm{v} / \mathrm{v}) \mathrm{SCV}$ of cells (15.2fold) proliferated in the original medium condition in $14 \mathrm{~d}$. At the $\log$ phase, mitotic activity characterized by tiny cytoplasmic dense cells which have strong fluorescence can be found in the cells especially those suspended in the revised medium by the Sytox Green staining (Figures $3 \mathrm{E}-\mathrm{G}$ ). With these findings, we tested transient expression levels of GUS gene in the various calli/suspension cells which showed weak/active growth features.

\section{Transient expression of GUS gene}

The strongest transient GUS gene expression was detected at 24-48 hours after a bombardment as shown in Figure 4. Effects of target cells and target distance on transient GUS gene expression were summarized in Table 1 . Since the $21 \mathrm{~d}$-old calli which showed higher proliferation capacity on solid revised medium (see Figure 2) was suitable for the transient gene expression in preliminary experiments, we then optimized the target distance for cell bombardment. In this experiment, log phased suspension cells maintained under the revised medium condition (11 and 13-d-old cells) were used. We found that a target distance, $6 \mathrm{~cm}$ was much better for the transient gene expression (222 GUS-positive cells/dish/ shot in average) than that of $9 \mathrm{~cm}$ (38 GUS-positive cells/dish/shot in average) in the target cells. When the bombardment was carried out using lag phased cells, e.g. 5-d-old cells, no or less GUS-positive cells could be seen.

\section{Stable expression of FP genes}

We performed particle bombardments with constructs both pBIH1-GFP and pBIH1-RFP. After the bombardments, the cells continued to proliferate during $14 \mathrm{~d}$ of culture and more than 400 cells per dish temporally expressed FP genes in this period. These cells were clearly visualized under a fluorescent stereo microscope and transferred to a selection medium supplemented with hygromycin. During subcultures at 2to 4-week intervals onto the fresh selection medium, a large number of antibiotic-resistant cell lines which showed strong expression of FP genes were easily detected (ca. 20-60 transformed cell lines/dish/shot were obtained). Since a strong autofluorescence feature could be seen in bamboo suspension cells under florescent light conditions, we analyzed emission spectra of both nontransformed and transformed cells using LSM. Several strong autofluorescence signals could be seen in nontransformed cells (Figure 5A; three major peaks around $450-550 \mathrm{~nm}$ in emission wavelength at $405 \mathrm{~nm}$ blue 

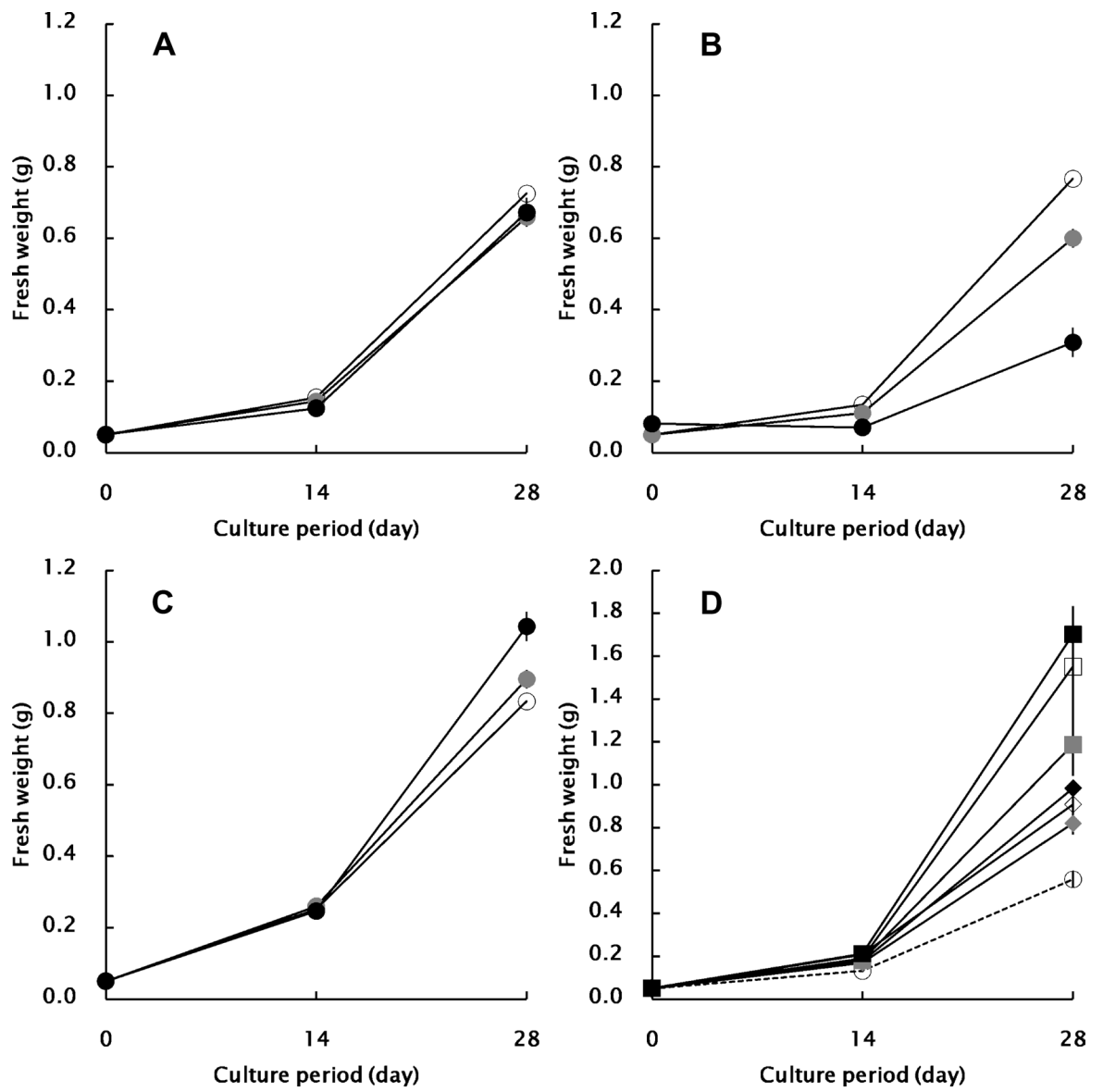

Figure 2. Growth profiles of bamboo calli. Effects of 2,4-D (A), 2,4,5-T (B), and Picloram (C) on callus growth. Open, gray, and closed circles indicate 3, 5, and $10 \mu \mathrm{M}$ of each auxin concentrations in half MS medium, respectively. Effects of $\mathrm{KH}_{2} \mathrm{PO}_{4}$ (D) on callus growth. Open circle indicates the original condition, i.e. half MS basal medium containing $85 \mathrm{mg}^{-1} \mathrm{KH}_{2} \mathrm{PO}_{4}$ and $3 \mu \mathrm{M}$ 2,4-D. Open, gray, and closed diamond symbols, indicate half MS basal media containing $10 \mu \mathrm{M}$ Picloram of which concentration of $\mathrm{KH}_{2} \mathrm{PO}_{4}$ varies 170 , 340, and $680 \mathrm{mg} 1^{-1}$, respectively. Similarly, square symbols indicate MS basal media containing $10 \mu \mathrm{M}$ Picloram of which concentration of $\mathrm{KH}_{2} \mathrm{PO}_{4}$ varies 170,340 , and $680 \mathrm{mg} 1^{-1}$, respectively. All data are expressed as mean $\pm \operatorname{SD}(n=6)$.

diode, $488 \mathrm{~nm}$ Argon, and $543 \mathrm{~nm} \mathrm{He}-\mathrm{Ne}$ laser conditions, one peak around $630 \mathrm{~nm}$ in emission wavelength at $633 \mathrm{~nm} \mathrm{He}-\mathrm{Ne}$ laser condition.). Images of the cells were also acquired around these wavelengths (Figure 5B). Based on this information, we finalized channel specifications for the detection of transformed cells. As shown in Figure 6A, a major fluorescence signal of $A c G F P 1$-expressing cells was separated from overlapping autofluorescence background of nontransformed wild type cells. Furthermore, a major fluorescence signal of $m$ Cherry-expressing cells was clearly separated from the background (Figure 6B). These cells showed detailed clear cytological images as shown in Figures 6C-F. Genomic DNA was extracted from 4 randomly selected independent 2 month-old transformed cells lines and subjected to PCR analysis using gene specific primers for $H P T$, and mCherry (Figure 7A). The fragments of each gene were successfully amplified. Furthermore, the result of RTPCR which was performed by using the total RNA prepared from 6 month-old genomic PCR-positive cells clearly indicated the stable transcription of the transgenes in the bamboo cells (Figure 7B). The same results were obtained from 4 independent AcGFP1expressing cell lines (data not shown).

\section{Discussion}

It is well known that optimization of the cell culture condition of target plant cells/tissues is one of the most important factors for transformation studies. For example, developmental stages and/or growth efficiency of target cells/tissues must be key factors for the regeneration of transformants (Cheng et al. 2004; Iida et al. 1991; Ogita et al. 2009). In order to construct transgenic bamboo cells with high efficiency, two problems had to be solved: establishment of an efficient suspension cell culture system and an improvement of the transformation procedure. We successfully established suspension cell culture system using a revised MS medium (MSp680) containing $10 \mu \mathrm{M}$ Picloram. Picloram was the best auxin for the proliferation of bamboo cells. 
A

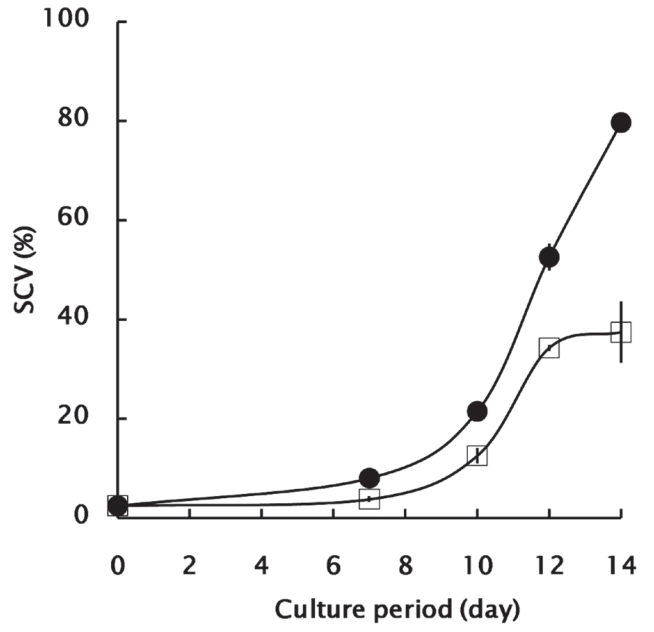

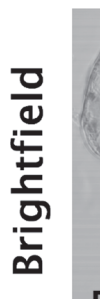

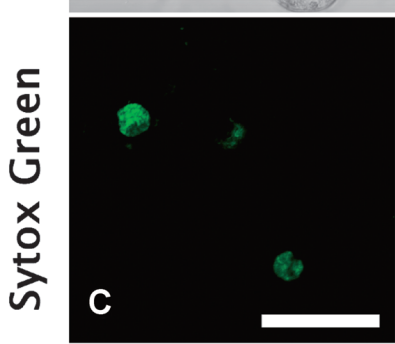

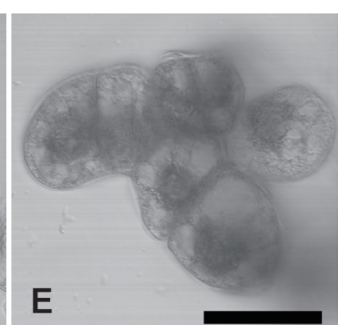

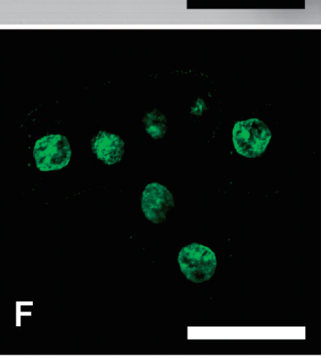

G

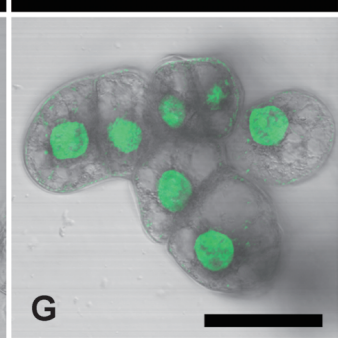

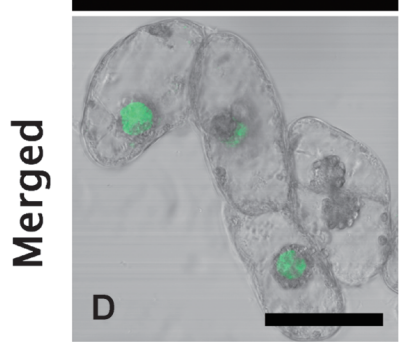

Figure 3. Growth and cell division of bamboo suspension cells. (A) Growth profiles of suspension cells in the original medium (open square) and the revised medium (closed circle). (B-D) 14-d-old cells cultured in the original medium. The SCV value was calculated as the percentage of sedimented cell volume $(\mathrm{ml})$ per $100 \mathrm{ml}$ medium. (E-G) 14-d-old cells cultured in the revised medium. Images were acquired using plane scan mode. Scale bars $=50 \mu \mathrm{m}$. The objective lens was a Plan-Apochromat $20 \times / 0.8$. Channel specification was as follow: Plane scan: Blue diode laser $405 \mathrm{~nm}, 15.8 \%$, Argon laser $488 \mathrm{~nm}, 2.0 \%$; Main Beam Splitter: HFT405/488/543/633; Beam Splitter 1: NFT 545; Beam Splitter 2: NFT 490; Filter; BP 420-480 IR, BP505-530.

Furthermore, $680 \mathrm{mg}^{-1} \mathrm{KH}_{2} \mathrm{PO}_{4}$, was quite effective for proliferation of the bamboo cells. Phosphate sources were well known as essential constituents for the regulation of cell growth and/or metabolic activities in plant species (Cowan 2006; Hagimori et al. 1982; Sugiyama et al. 1986). MSp680 medium condition

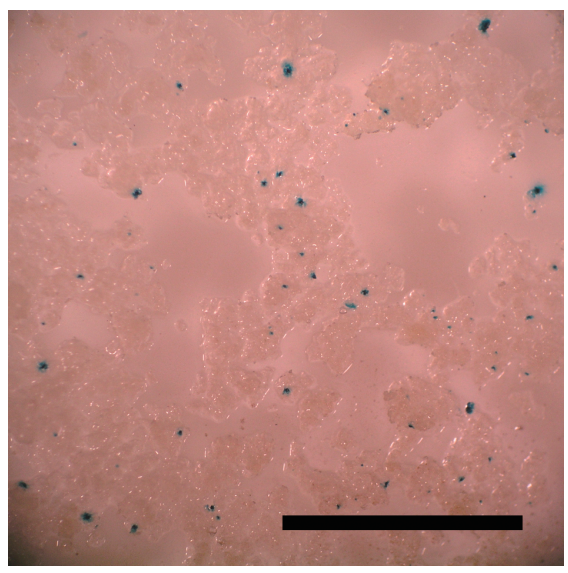

Figure 4. Histochemical GUS gene expression in bamboo suspension cells. Scale bar $=5 \mathrm{~mm}$.

Table 1. Transient GUS gene expression in bamboo calli and suspension cells

\begin{tabular}{|c|c|c|c|}
\hline Tissues & $\begin{array}{l}\text { Target } \\
\text { distance } \\
(\mathrm{cm})\end{array}$ & $\begin{array}{c}\text { Number of } \\
\text { GUS- } \\
\text { expressing } \\
\text { cells/dish/shot }\end{array}$ & Mean \pm SD \\
\hline $\begin{array}{l}\text { 21d-old-calli derived from } \\
1 / 2 \mathrm{MS}(3 \mu \mathrm{M} 2,4-\mathrm{D})\end{array}$ & 6 & $\begin{array}{l}1 \\
6\end{array}$ & 4 \\
\hline $\begin{array}{l}\text { 21d-old-calli derived from } \\
\text { MSp680 (10 } \mu \mathrm{M} \text { Pic) }\end{array}$ & 6 & $\begin{array}{l}10 \\
45\end{array}$ & 28 \\
\hline \multirow[t]{2}{*}{$\begin{array}{l}\text { 11d-old-suspension cells } \\
\text { derived from MSp680 } \\
(10 \mu \mathrm{M} \text { Pic) }\end{array}$} & 6 & $\begin{array}{l}101 \\
110 \\
145\end{array}$ & $119 \pm 13$ \\
\hline & 9 & $\begin{array}{r}9 \\
12 \\
35\end{array}$ & $19 \pm 8$ \\
\hline \multirow[t]{2}{*}{$\begin{array}{l}\text { 13d-old-suspension cells } \\
\text { derived from MSp680 } \\
\text { (10 } \mu \text { M Pic) }\end{array}$} & 6 & $\begin{array}{l}117 \\
209 \\
339\end{array}$ & $222 \pm 64$ \\
\hline & 9 & $\begin{array}{c}2 \\
37 \\
75\end{array}$ & $38 \pm 21$ \\
\hline
\end{tabular}

allows the supply of homogenous bamboo cells within $14 \mathrm{~d}$. Furthermore, histological observation using LSM clearly indicated that the cells have active proliferation capacity during days $8-14$ of the culture period. High mitotic activity characterized by tiny cytoplasmic dense cells indicating that the mitotic processes are quite synchronous at this period within the cell population. There is evidence that the efficiency of the particle bombardment mediated transformation was influenced by cell cycle stages in BY-2 cells (Iida et al. 1991). Based on these findings, we focused our efforts on determining the most suitable stage for transformation using the particle bombardment method. Transient expression of the GUS gene in the log phased suspension cells indicated that cells having active growth efficiency 
A

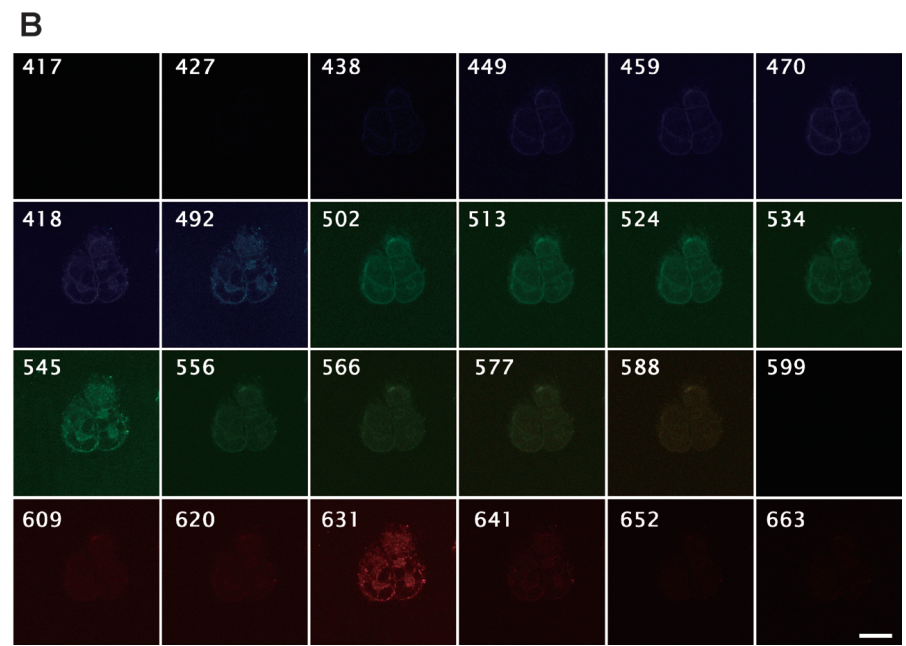

Figure 5. LSM imaging of non-transformed cells. (A) Emission spectra. (B) Images of autofluorescence signals of the cells. Scale bar $=50 \mu \mathrm{m}$. The objective lens was a Plan-Apochromat 20×/0.8. Channel specification was as follow: Plane lambda scan: Blue diode laser $405 \mathrm{~nm}, 15 \%$, Argon laser $488 \mathrm{~nm}, 10.0 \%$; He-Ne laser 543 nm, 30.0\%, He-Ne laser 633 nm, 10\%; Main Beam Splitter: HFT405/488/543/633; Filter; 411-700.
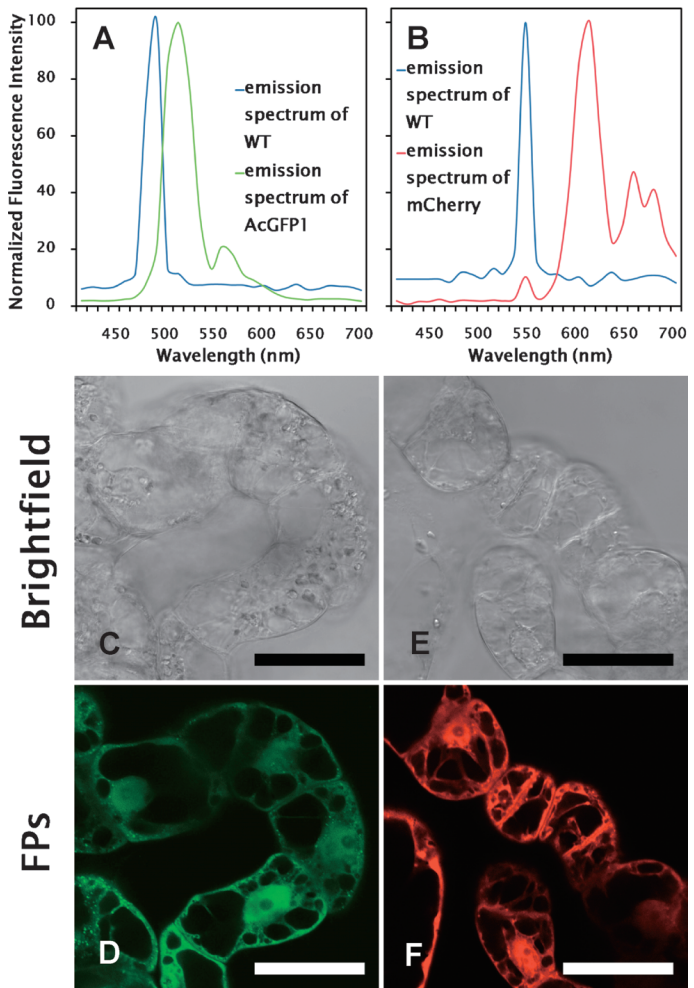

Figure 6. LSM imaging of transformed cells. (A) Emission spectra of $A c G F P 1$-expressing cells and non transformed wild type cells at $488 \mathrm{~nm}$ Argon laser condition. (B) Emission spectra of mCherryexpressing cells and non transformed wild type cells at $543 \mathrm{~nm} \mathrm{He}-\mathrm{Ne}$ laser condition. The spectra data was acquired using lambda scan mode. (C-D) Images of AcGFP1-expressing cells. (E-F) Images of $m$ Cherry-expressing cells. Images were acquired using plane scan mode. Scale bars $=50 \mu \mathrm{m}$. The objective lens was a Plan-Apochromat $20 \times / 0.8$. Channel specifications were as follows: Plane lambda scan: Argon laser $488 \mathrm{~nm}, 10.0 \%$; He-Ne laser $543 \mathrm{~nm}, 30.0 \%$; Main Beam Splitter: HFT405/488/543/633; Filter; 411-700. Plane scan (AcGFP1): Argon laser $488 \mathrm{~nm}, 7.9 \%$; Main Beam Splitter: HFT405/488; Beam Splitter 1: mirror; Beam Splitter 2: mirror; Filter; BP 505-530. Plane scan (mCherry): He-Ne laser $543 \mathrm{~nm}, 16.8 \%$; Main Beam Splitter: HFT488/543; Beam Splitter 1: mirror; Beam Splitter 2: NFT 545; Filter; LP 560.

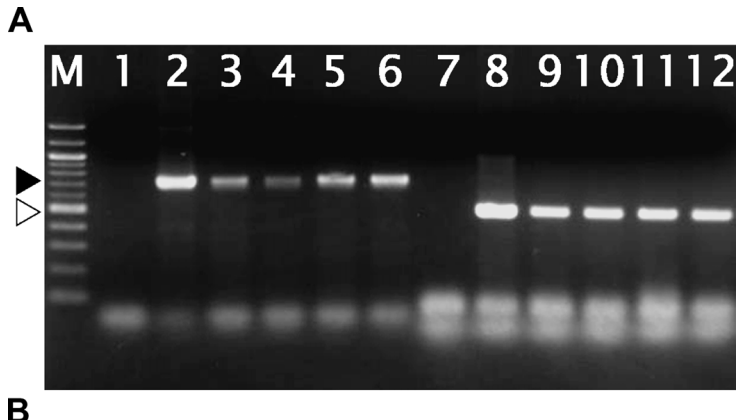

B

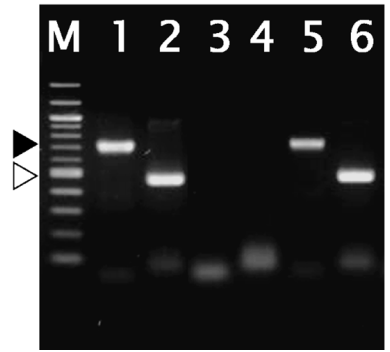

Figure 7. (A) Genomic PCR of transformed cells. M; 100-bp ladder marker, lanes 1 and 7; non-transformed cells, lanes 2 and 8; vector control, lanes 3-6 and 9-12; transformed cells (3-9, 4-10, 5-11, and 6-12 are independent cell lines). The expected fragments (closed triangle; 713-bp for HPT, open triangle; 459-bp for $m$ Cherry) were amplified from vector control and genomic DNAs of transformed cells. (B) RT-PCR of transformed cells. M; 100-bp ladder marker, lanes 1, 3, 5; HPT, lanes 2, 4, 6; mCherry. The expected fragments (closed triangle; 713-bp for HPT, open triangle; 459-bp for $m$ Cherry) were amplified from vector control (lanes 1 and 2) and cDNA (lanes 5 and 6). None of fragments amplified from RNA without reverse transcription suggests that no genomic DNA is contaminated (lanes 3 and 4).

were ideal targets for transformation. Furthermore, we found that a distance of $6 \mathrm{~cm}$ was the optimal distance for bombardment. The efficiency of the gene expression at $6 \mathrm{~cm}$ target distance was at least 5 times higher than that of $9 \mathrm{~cm}$ target distance in average (Table 1).

Since hygromycin is a useful reagent for the selection 
of transformants in monocotyledonous plant species, such as barley (Um et al. 2007), orchid (Chang et al. 2005), rice (Hiei et al. 1994; Sudhakar et al. 1998), and sugarcane (Arencibia et al. 1998), we preliminary investigated whether this reagent is effective for the selection of possibly transformed bamboo cells. We used kanamycin, geneticin and hygromycin as candidates for the selection. The result clearly indicated that only hygromycin showed the specificity towards bamboo suspension cells (data not shown). We have reported that the bamboo suspension cells had a high proliferation potential with abundant deposition of cell wall compounds (Ogita 2005). A strong autoflorescence feature could be detectable when observed suspension cells under florescent light conditions (Ogita et al. 2008). Although such overlapping signals could be mechanically separated from a target signal by using suitable filter(s), illumination(s), and/or function(s) of the microscope system used, the high background during cell imaging can still generate artifact. Therefore, we used enhanced FP genes namely AcGFPl (Bell et al. 2007) and $m$ Cherry (Wu et al. 2009) and checked their efficacy. These two types of FP were successfully translated in bamboo cells and their major fluorescence signals could be separated from the background of bamboo suspension cells at $488 \mathrm{~nm}$ of Argon and $543 \mathrm{~nm}$ of $\mathrm{He}-\mathrm{Ne}$ laser conditions for $A c G F P 1$ and $m$ Cherry, respectively. These FP expressing cells showed detailed clear cytological images as shown in Figures 6C-F. Since a useful configuration of the Zeiss LSM 510 for simultaneous optical separation of green and red FPs has been established (Anderson et al. 2006), our findings show promise for further analytical works using these FP genes and LSM imaging in bamboo suspension cells.

In the present study, a practical transformation protocol for P. nigra was successfully achieved using a cell suspension culture system. To the best of our knowledge, this is the first detailed information on the transformation of cultured bamboo cells. These transgenic techniques can be used as a tool for further characterization of physiological and molecular biological events such as the xylogenesis and lignification process of bamboo species. Such studies are now in progress.

\section{Acknowledgements}

The corresponding author thanks Professor Edward C. Yeung of the University of Calgary for critically reading the manuscript. The author also thanks Mr. Tatsuhiro Iwaki of Toyama Prefectural University for technical assistance. This research was supported in part by a Grant-in-Aid for scientific research, C (22580387) from the Japan Society for the Promotion of Science.

\section{References}

Anderson KI, Sanderson J, Gerwig S, Peychl J (2006) A new configuration of the Zeiss LSM 510 for simultaneous optical separation of green and red fluorescent protein pairs. Cytometry Part A 69: 920-929

Arencibia AD, Carmona ER, Tellez P, Chan MT, Yu SM, Trujillo LE, Oramas P (1998) An efficient protocol for sugarcane (Saccharum spp. L.) transformation mediated by Agrobacterium tumefaciens. Transgenic Res 7: 213-222

Baba A, Hasezawa S, Syono K (1986) Cultivation of rice protoplasts and their transformation mediated by Agrobacterium spheroplasts. Plant Cell Physiol 27: 463-471

Bell P, Vandenberghe LH, Wu D, Johnston J, Limberis M, Wilson JM (2007) A comparative analysis of novel fluorescent proteins as reporters for gene transfer studies. J Histochem Cytochem 55: 931-939

Chang C, Chen YC, Hsu YH, Wu JT, Hu CC, Chang WC, Lin NS (2005) Transgenic resistance to Cymbidium mosaic virus in Dendrobium expressing the viral capsid protein gene. Transgenic Res 14: 41-46

Cheng M, Lowe BA, Spencer TM, Ye X, Armstrong CL (2004) Factors influencing Agrobacterium-mediated transformation of monocotyledonous species. In Vitro Cell Dev Biol-Plant 40: $31-45$

Cowan AK (2006) Phospholipids as plant growth regulators. Plant Growth Regul 48: 97-109

Hagimori M, Matsumoto T, Obi Y (1982) Studies on the production of Digitalis cardenolides by plant tissue culture III. Effect of nutrients on Digitoxin formation by shoot-forming cultures of Digitalis purpurea L. grown in liquid media. Plant Cell Physiol 23: 1205-1211

Hiei Y, Ohta S, Komari T, Kumashiro T (1994) Efficient transformation of rice (Oriza sativa L.) mediated by Agrobacterium and sequence analysis of the boundaries of the TDNA. Plant J 6: 271-282

Iida A, Yamashita T, Yamada Y, Morikawa H (1991) Efficiency of particle-bonbardment-mediated transformation is influenced by cell cycle stage in synchronized cultured cells of Tobacco. Plant Physiol 97: 1585-1587

Kosugi S, Ohashi Y, Nakajima K, Arai Y (1990) An improved assay for $\beta$-glucuronidase in transformed cells: methanol almost completely suppresses a putative endogenous $\beta$-glucuronidase activity. Plant Sci 70: 133-140

Lee LY, Fang MJ, Kuang LY, Gelvin SB (2008) Vectors for multicolor bimolecular fluorescence complementation to investigate protein-protein interactions in living plant cells. Plant Meth 4: 24

Murashige T, Skoog F (1962) A revised medium for rapid growth and bioassays with tabacco tissue cultures. Physiol Plant 15: 473-479

Nagata T, Nemoto Y, Hasezawa S (1992) Tobacco BY-2 cell line as the HeLa cell in the cell biology of higher plants. Int Rev Cytol 132: $1-30$

Nagata T, Kumagai F (1999) Plant cell biology through the window of the highly synchronized tobacco BY-2 cell line. Meth in Cell Sci 21: 123-127

Ogita S (2005) Callus and cell suspension culture of bamboo plant, Phyllostachys nigra. Plant Biotechnol 22: 119-125

Ogita S, Ohki S, Kato Y (2008) Uptake of carbohydrates by suspension cultured cells of bamboo plants. In: Teixeira da Silva JA (ed) Floric Ornam and Plant Biotechnol vol 5 Global 
Science Books, Isleworth, UK, pp 240-244

Ogita S, Usui M, Shibutani N, Kato Y (2009) A simple shoot multiplication procedure using internode explants, and its application for particle bombardment and Agrobacteriummediated transformation in watercress. J Plant Res 122: 455-463

Ohta S, Mita S, Hattori T, Nakamura K (1990) Construction and expression in tobacco of a $\beta$-glucuronidase (GUS) reporter gene containing an intron within the coding sequence. Plant Cell Physiol 31: 805-813

Sudhakar D, Duc LT, Bong BB, Tinjuangjun P, Maqbool SB, Valdez M, Jefferson R, Christou P (1998) An efficient rice transformation system utilizing mature seed-derived explants and a portable, inexpensive particle bombardment device. Transgenic Res 7: 289-294

Sugiyama M, Fukuda H, Komamine A (1986) Effects of nutrient limitation and $\gamma$-irradiation on tracheary element differentiation and cell division in single mesophyll cells of Zinnia elegans. Plant Cell Physiol 27: 601-606

Um MO, Park TI, Kim YJ, Seo HY, Kim JG, Kwon SY, Kwak SS, Yun DJ, Yun SJ (2007) Particle bombardment-mediated transformation of barley with an Arabidopsis NDPK2 cDNA. Plant Biotechnol Rep 1: 71-77

Wu B, Chen Y, Muller JD (2009) Fluorescence fluctuation spectroscopy of mCherry in living cells. Biophysical $J 96$ : 2391-2404 